\title{
The possible use of surian tree (Toona sinensis Roem) branches as an alternative raw material in the production of composite boards
}

\author{
Eka Mulya Alamsyah*, Sutrisno, Ihak Sumardi, Atmawi Darwis, Yoyo Suhaya and Yayat Hidayat
}

\begin{abstract}
The current research focuses on the utilization of branches and twigs of surian as raw material for making composite boards in an effort to utilize the waste part of surian stem wood waste. The types of particle board and oriented strand board were bonded with phenol formaldehyde (PF) of 10\% resin content. Variations of board density and board types were focused in this research. The boards were evaluated based on Japanese Industrial Standard (JIS). The results showed that the density of the board affected the physical and mechanical properties of the composite board. Strand boards were better than particle boards with regard to mechanical properties. Physical properties that met the testing standards were moisture content, density, water absorption and thickness swell for both after soaking $2 \mathrm{~h}$ in water, while for the mechanical properties test, only modulus of elasticity (MOE) met the standards. However, for further study, it seemed that generally this initial study informed that it was possible to make composite boards from the raw materials, both branches and twigs, with the additional treatment such as changing the size of particles and strands that could improve the properties of the board.
\end{abstract}

Keywords: Branches, Particle board, Strand board, Toona sinensis, Twigs

\section{Introduction}

Utilization of fast growing wood from the plantation forest, leaving various problems in the efficiency of raw materials, especially branches and twigs. The large number of branches and twigs that are wasted resulted in smaller utilization than the volume of timber harvested, so that there is wood waste that is not transported in felling plots and landfills. Waste of harvesting is a part of the stem such as branches and twigs that comes from harvesting activities that are not utilized and left in the forest [1]. This happens due to skidding and logging activities. The results of Muhdi and Hanafiah [2] research revealed that the damage to standing trees at pole and tree levels reached $33 \%$ in conventional harvesting and $19.5 \%$ in reduced-impact logging systems.

*Correspondence: ekamulya@sith.itb.ac.id

School of Life Sciences and Technology, Institut Teknologi Bandung, Jalan Ganesa 10, Bandung 40132, Indonesia
Currently, the problem of wood waste is starting to get greater attention from timber entrepreneurs. This is due to the emergence of the tendency that the raw material of the timber industry is increasingly diminishing. Therefore, the volume of wood waste needs to be kept to a minimum, namely by carrying out proper harvesting activities and through the utilization of waste. One of the efforts to use wood waste is to use it as a raw material for particle board [3]. Particle board is a panel product made from lignocellulosic materials including the main wood in the form of particles glued with synthetic resin under hot pressing [4]. Synthetic resins which have often been used are generally urea formaldehyde (UF) and phenol formaldehyde (PF). In this study, besides using UF resin, a mixture of UF and isocyanate is also used. This is intended to increase strength [5] and reduce thickness swelling [6] because thickness swelling is still a problem on particle boards [7]. In previous studies, much additional substrate used such as porcelain stone which was used to reduce the value of thickness swelling of composite board 
made of pruning wood [8]. Utilization of pruning waste of seven types of wood from Saudi Arabia to make composite boards still shows lower physical and mechanical properties compared to composite boards manufactured from stem parts. It still requires a time of study and additional treatment to improve the boards' properties [9]. Chung and Wang [10] stated that the use of bamboo and wood waste can be done to improve the properties of composite boards.

A similar study was conducted by Rahman et al. [11] who used the stem and branch sections of wood as a material for making particle boards with the results showing that the particle board of the stem part had better properties than the particleboard made of the branch, but both of them had met the testing standards. Maraghi and Tabei [12] has already succeeded in making the possible use of poplar wood slab mixed with citrus branches and twigs of beech as material for particle board production under various density targets to improve the mechanical properties of the particle board. These two previous studies indicated that the characteristics of the particleboard are still influenced by the wood section from the stem part. However, in this current study, the characteristics of the particleboard depend only on the branches and twigs part in accordance with the objective of this study.

Related to the study on the whole utilization of surian wood parts, previously, the stem part of surian wood has been investigated and targeted for use in laminated wood productions [13]. The current research focuses on the utilization of branches and twigs of surian in the form of particles and strands as materials for making particleboard and strand board in an effort to utilize the waste surian wood stems.

\section{Materials and methods}

\section{Experimental}

Particles preparation

Wood particles are made from parts of surian wood branches and twigs with the help of a particle making machine (flaker); whereas for making flake is done by cutting branches and twigs, then flake is made by cutting it with a target size of $50 \mathrm{~mm}$ in length with variations in thickness from 0.3 to $1.5 \mathrm{~mm}$ and widths of $10-20 \mathrm{~mm}$. Before drying, both flake and particles are screened using a 10-mesh sieve. Flake and particles are dried in a rotary oven until they reach $5 \%$ moisture content at a temperature of $60{ }^{\circ} \mathrm{C}$. The manufacture of particles and flakes was carried out in the Laboratory of Forestry Engineering, School of Life Sciences and Technology, Bandung Institute of Technology.

\section{Composite board production}

Particle boards and oriented strand boards (OSB) are made with a size of $30 \mathrm{~cm} \times 30 \mathrm{~cm} \times 1 \mathrm{~cm}$ with a target density of $0.5,0.7$ and $0.9 \mathrm{~g} / \mathrm{cm}^{3}$ and adhesive content of $10 \%$ of the oven-dried weight of the particle. Particles from the wooden branches of the surian are symbolized as wood $C$ and the twigs as wood $R$. The number of test samples and their composition is explained in Table 1.

The production of particle board and OSB is done by spraying the surface of the particles with a sprayer through the gap in the blender, while the blender continues to be rotated so that the raw material and adhesive are evenly mixed. Particle boards are made using liquid PF adhesive obtained from PT. Pamolite Adhesive, a wood adhesives company in Jakarta, Indonesia. The PF adhesive has a solid adhesive content of $51 \%$ and the adhesive content used is $10 \%$. The adhesive mixture with particles is then formed into sheets using a mold measuring $30 \mathrm{~cm} \times 30 \mathrm{~cm}$, then heated at a temperature of $135{ }^{\circ} \mathrm{C}$ with a pressure of $1 \mathrm{MPa}$ until it reaches a thickness of $1 \mathrm{~cm}$ using a 1 -cm-thick iron pad. After $10 \mathrm{~min}$ of hot pressing, conditioning is then carried out by storing the board in a room that has good air circulation for 1 week to achieve equilibrium moisture content. The board is made of three sheets per each treatment; therefore, the total number is 18 boards.

\section{Table 1 Composition of composite board production}

\begin{tabular}{|c|c|c|c|c|c|}
\hline $\begin{array}{l}\text { Target of density }(\mathrm{g} / \\
\left.\mathrm{cm}^{3}\right)\end{array}$ & Sources of particles & Code & Total no. of boards & Type of composites & $\begin{array}{l}\text { Total no. } \\
\text { of layers }\end{array}$ \\
\hline 0.5 & Branches & $\mathrm{O} 5 \mathrm{C}$ & 3 & OSB & 1 \\
\hline 0.7 & Branches & O7C & 3 & OSB & 1 \\
\hline 0.9 & Branches & O9C & 3 & OSB & 1 \\
\hline 0.7 & Twigs & O7R & 3 & OSB & 1 \\
\hline 0.7 & Twigs & P7R & 3 & Particleboard & 1 \\
\hline 0.7 & Twigs & OPO7R & 3 & OSB/particleboard/OSB (1:1:1) & 3 \\
\hline
\end{tabular}

O: strand board; P: particle board; 5 : density $0.5 \mathrm{~g} / \mathrm{cm}^{3}$; C: branches; R: twigs 


\section{Physical and mechanical properties test}

Physical and mechanical properties tests of particleboard and strand board were carried out based on JIS A 5908 [14]. The physical properties tested were moisture content, density, water absorption and thickness swelling, while the testing of mechanical properties was carried out to determine the increase in strength due to differences in density and different types of composite board. The tests carried out were the flexural bending test (MOE/modulus of elasticity and MOR/modulus of rupture) and the internal bond strength by using Instron Universal (AG-IS $50 \mathrm{kN}$, Shimadzu) testing equipment with a span of $280 \mathrm{~mm}$. The size of test sample for MOR and MOE was $350 \mathrm{~mm} \times 50 \mathrm{~mm} \times 12 \mathrm{~mm}$. MOR testing was carried out under air-dry conditions. The test was done by applying a maximum load with one point load at speed load of $10 \mathrm{~mm} /$ minute until the test sample breaks.

MOR is calculated by the formula:

$$
\mathrm{MOR}=(3 P L) /\left(2 b h^{2}\right)
$$

where MOR is the modulus of rupture; $P$, the maximum load (kgf); $L$, the span (cm); $b$, the width of the test sample $(\mathrm{cm})$; and $h$, the thickness of the test sample $(\mathrm{cm})$.

MOE testing is carried out during air-dry conditions. The test sample is loaded until the test sample has a maximum deflection. MOE is calculated by the formula:

$$
\operatorname{MOE}=\left((\Delta P)(L)^{3}\right) /\left(4\left(\Delta y b h^{3}\right),\right.
$$

where MOE is the modulus of elasticity $\left(\mathrm{kgf} / \mathrm{cm}^{2}\right) ; \Delta P$, the load change (kgf); $L$, the span $(\mathrm{cm}) ; b$, the width of the test sample $(\mathrm{cm}) ; h$, the thickness of the test sample $(\mathrm{cm})$; and $\Delta y$ is the deflection due to the load $(\mathrm{cm})$.

\section{Data processing}

This study consisted of two treatments, board density as the first treatment consisted of three levels, namely $0.5 ; 0.7$ and $0.9 \mathrm{~g} / \mathrm{cm}^{3}$ and the type of composite board treatment consisted of strand board and particleboard. A two-way analysis of variance (ANOVA) and Duncan's multiple range test were used to analyze the data. All statistical tests were performed using SAS at a 95\% confidence level.

\section{Results and discussion \\ Physical properties \\ Moisture content and density}

Target density of composite board is in the range of $0.5-0.9 \mathrm{~g} / \mathrm{cm}^{3}$, the distribution of values that occur at the target density was $\pm 0.73 \mathrm{~g} / \mathrm{cm}^{3}$. From these results, the values obtained are relatively good that meet the requirements of the JIS A 5908 [14] standard, except for the target density of $0.5 \mathrm{~g} / \mathrm{cm}^{3}$. In general, the results of particle board and strand board moisture content testing are lower than the moisture content of the raw material/ wood. This occurs as a result of heat treatment received by the board during hot presses [15].

As shown in Table 2, the distribution conditions of particle board and strand board moisture content after being conditioned for 1 week ranged between 11.4 and $13.8 \%$. This condition indicates that the water content achieved has reached equilibrium, where the condition of the moisture content will adjust to the environmental conditions in which the material is placed. The increasing density of the board is in line with the increasing of moisture content of the board. In general, there are no significant differences in the final moisture content conditions in all test samples made and they fulfilled the requirements of JIS A 5908 [14] which requires moisture content of 11.4-13.8\%. However, the particle board tends to have a slightly higher moisture content than strand board, for particle board (P7R) has a moisture content of $13.2 \%$ while that of the strand board $(\mathrm{O} 7 \mathrm{R})$ is $11.1 \%$; it is suspected that the particle boards are composed of particles smaller than the flake boards and have a larger surface area, so the chance of absorbing water from the

\begin{tabular}{|c|c|c|c|c|c|c|}
\hline \multirow[t]{2}{*}{ Code } & \multirow{2}{*}{$\begin{array}{l}\text { Target of density }(\mathrm{g} / \\
\left.\mathrm{cm}^{3}\right)\end{array}$} & \multirow{2}{*}{$\begin{array}{l}\text { Moisture content } \\
\text { (\%) }\end{array}$} & \multicolumn{2}{|c|}{ Weight gain (\%) } & \multicolumn{2}{|c|}{ Thickness swell (\%) } \\
\hline & & & $2 \mathrm{~h}$ & $24 \mathrm{~h}$ & $2 \mathrm{~h}$ & $24 \mathrm{~h}$ \\
\hline $\mathrm{O} 5 \mathrm{C}$ & 0.5 & 11.4 & $22.85(9.22)$ & $46.91(9.64)$ & $6.43(1.99)$ & $14.53(3.96)$ \\
\hline O7C & 0.7 & 12.8 & $17.47(3.35)$ & $43.26(5.74)$ & $8.83(3.75)$ & $20.78(6.73)$ \\
\hline O9C & 0.9 & 12.8 & $15.76(1.12)$ & $37.93(2.80)$ & $8.86(1.51)$ & $21.94(3.80)$ \\
\hline O7R & 0.7 & 11.9 & $19.81(3.06)$ & $46.73(5.92)$ & $11.65(1.19)$ & $24.51(4.24)$ \\
\hline P7R & 0.7 & 13.2 & $39.87(3.16)$ & $74.84(0.53)$ & $30.88(1.56)$ & $49.46(5.07)$ \\
\hline OPO7R & 0.9 & 13.8 & $23.49(3.81)$ & $55.86(6.51)$ & $14.66(1.82)$ & $31.41(4.63)$ \\
\hline
\end{tabular}

Table 2 Physical properties at various compositions

Values in parentheses are standard deviations 
environment is much greater than the flake boards. Similar phenomenon had been shown by Chung and Wang [10].

\section{Water absorption}

The test results of water absorption are clearly shown in Table 2; it can be seen that the average absorption capacity of strand board water and particle board after soaking for 2 and $24 \mathrm{~h}$ in all treatment conditions. Water absorption for $2 \mathrm{~h}$ ranged between 17.47 and $39.87 \%$ and in the 24-h bath increased to $37.93-74.84 \%$. Differences in water absorption capacity occur in the types of boards; particle boards tend to have a higher water absorption than strand board both at 2-h and 24-h soaking, while the effect of density on strand board does not show a significant difference at $95 \%$ confidence level.

The difference in particle size between flake and particles in the type of board made is one of the factors that cause differences in water absorption. The surface area exposed directly is thought to be one of the causes of the amount of water absorption in addition to the gap between the particles. The resulting value is aligned with the value of the water content between the two types of boards made. In general, the amount of water absorption data is not a requirement specified in JIS A 5908 [14] Standard, but this parameter is one of the indications that the level of stability of the board will affect the thickness swell.

\section{Thickness swell}

The thickness swell of composite products is one of the limiting factors on the dimensional stability of composite products in addition to moisture content and water absorption capacity which are all related. The high thickness swell could cause unstable composite products that could affect their strength and other uses. The thickness swell after the soaking treatment for $2 \mathrm{~h}$ ranged from 6.43 to $30.88 \%$ and after soaking for $24 \mathrm{~h}$ ranged from 14.53 to $49.46 \%$ (Table 2).

The difference in thickness swell occurs between particle board and strand board, the thickness swell of the strand board tends to be smaller both for $2 \mathrm{~h}$ and $24 \mathrm{~h}$ compared to particle boards. The same thing happens between the branch material and the twigs on the strand board. The flake of the branch tends to result a smaller thickness swell than the flake of the twigs on strand board. This occurs because the characteristics of the branch are different from the twigs, especially in the length of the fiber, this is in line with the statement of Okai et al. [16] and Bowyer et al. [7] that the origin of raw materials, wood from branching has lower properties than main stem wood. The high thickness swell on the particle board can be reduced by a combination of layers with strand board. As with the three-layer board test (OPO7R), it can reduce the development of homogeneous particle board (P7R) thickness even though the resulting value is still above the standard required by JIS A 5908 [14]; whereas the difference in density on the strand board is not seen significantly with a small difference between the thickness of the board (2\%). Hermawan et al. [8] reported that the use of waste porcelain stone can reduce the value of thickness swelling of particleboard made from pruning wood.

\section{Modulus of rupture and modulus of elasticity}

MOR shows maximum load that can be held per unit area until broken. The value obtained from the MOR test is at $4.3-8.4 \mathrm{kgf} / \mathrm{cm}^{2}$ with the largest value occurring at a density of $0.9 \mathrm{~g} / \mathrm{cm}^{3}$. The results of strand board of branches material showed an increase in MOR along with increasing density (O5C, O7C and $\mathrm{O} 9 \mathrm{C})$ especially at densities of 0.5 and $0.7 \mathrm{~g} / \mathrm{cm}^{3}$. The difference in strength due to density differences is very common in composite products. This is due to the more compact material due to the pressure applied to the particles, while for the use of branches and twigs on the strand board of the density of $0.7 \mathrm{~g} / \mathrm{cm}^{3}$ has not shown a significant difference.

The type of composite will affect the MOR value seen from the significant difference between particle board and strand board on a board with a density of $0.7 \mathrm{~g} /$ $\mathrm{cm}^{3}$ (O7R and P7R), where the value of the MOR strand board was higher than the particle board. Longer particle sizes have a positive contribution to strength values and the improving particle board strength can be done by coating the face and back of the board with a strand board layer such as on a 3-layer board (OPO7R) where the MOR value is between the MOR values of the particle board and strand board (Fig. 1). This reinforces that the combination of 3 layers between the strand board-strand board can be used to increase the strength and utilization of all materials from wood.

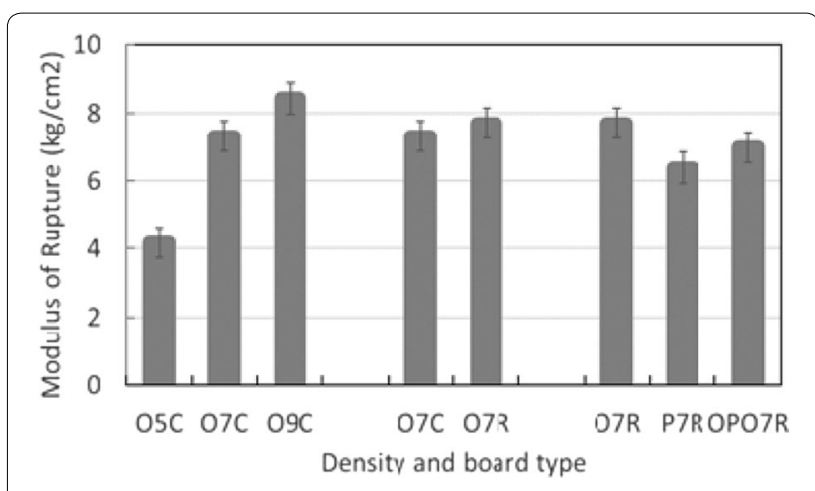

Fig. 1 Modulus of rupture in various composite board compositions 


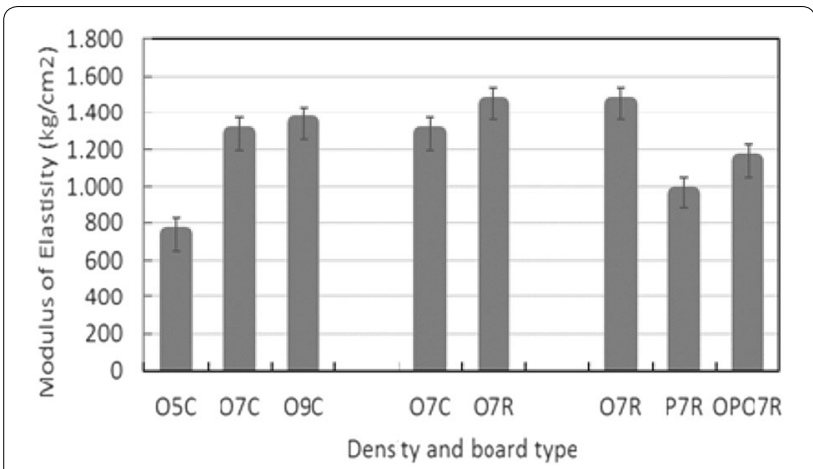

Fig. 2 Modulus of elasticity in various composite board compositions

In general, the MOR values obtained from the board did not meet the JIS A 5980 [14] standard. The low MOR value is thought to be due to the particle board in this study being made from the fast-growing branches. This is in accordance with Marra [17] who stated that the strength of reconstituted wood products, including particle board, tends to diminish as the wood constituent elements shrink when compared to the same density. As a result, when testing the MOR, the particle board is unable to withstand the test load. Likewise with the origin of raw materials, wood from branches has lower properties than main stem wood $[7,16]$.

Modulus of elasticity or modulus of rigidity is a measure of resistance in holding the load before breaking (to the extent of proportion). The higher the modulus of elasticity, the higher is the rigidity. There is a very strong relationship between the MOR and MOE values. The resulting particle board MOE value has the same tendency as MOR, which is lower than the strand board as in Fig. 2. In general, the values obtained in all treatment conditions are $800-1500 \mathrm{kgf} / \mathrm{cm}^{2}$. This value has met the JIS Standard A 5908 type 8 [14], which requires a minimum MOE value of $2000 \mathrm{~N} / \mathrm{mm}^{2}$ which is equivalent to $204 \mathrm{kgf} / \mathrm{cm}^{2}$.

\section{Internal bond}

Internal bond (IB) testing is an important indicator of the quality of composites. This indicator shows the strength of the adhesive to bind to the particles that make up the particle board. Figure 3 shows the internal bond of the particleboard and strand board in various test conditions.

In general, there is an increase in IB with increasing density of the strand board. This is because the board with high density has a thicker cell wall and is more compacted between particle and adhesive. The use of $10 \%$ phenol formaldehyde adhesive in the manufacture of composite boards with material from branches and twigs was not sufficient to meet the requirements for internal

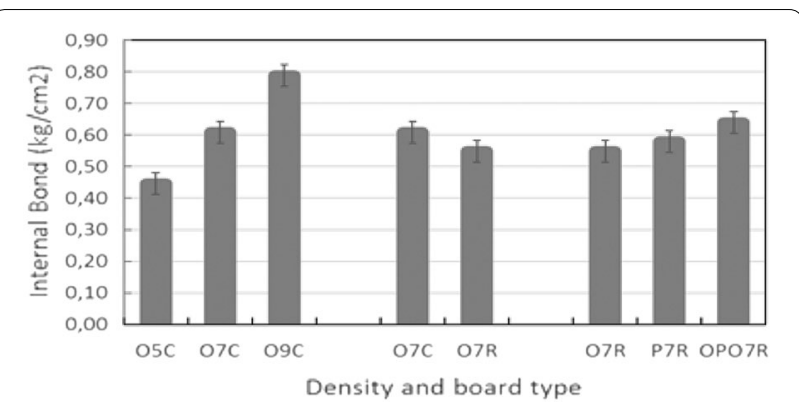

Fig. 3 Internal bond in various composite board composition

bond quality of the JIS A 5908 [14] where the minimum standard is $1.5 \mathrm{kgf} / \mathrm{cm}^{2}$. The low value of IB can be due to the low bond strength between the adhesive and adherents. This is presumably when the distribution of adhesive is less even. Bowyer et al. [7] states that IB is influenced by blending (mixing particles with adhesive), sheet formation and pressing. The other reason is that the density of branches is higher than the density of twigs causing the IB of the branch boards to be higher than the twig boards. Intimate contact between the particles and the adhesive in a particle board leads to a larger bonding area compared with a strand board so that the IB of the particle board was higher than the strand board.

\section{Conclusions}

Surian wood branches and twigs can generally be used as a raw material for composite products. The most suitable type is flake-shaped particles for strand board products. The use of other forms such as particles must be combined with flakes for better strength.

Physical properties that meet the testing standards were moisture content, density, water absorption and thickness swell for both when soaked for $2 \mathrm{~h}$ in water. While for the mechanical properties test, only MOE had met the standards.

For the subsequent studies, the improvement in technology on producing flakes and particles shapes is one of the important aspects in accordance with the increased utilization of surian wood branches and twigs for composite products.

\section{Abbreviations}

PF: Phenol formaldehyde; UF: Urea formaldehyde; MOE: Modulus of elasticity; MOR: Modulus of rupture; ANOVA: Analysis of variants; IB: Internal bond; O5C: Oriented strand board made from branches with the density target of $0.5 \mathrm{~g} / \mathrm{cm}^{3}$; O7C: Oriented strand board made from branches with the density target of $0.7 \mathrm{~g} / \mathrm{cm}^{3}$; O9C: Oriented strand board made from branches with the density target of $0.9 \mathrm{~g} / \mathrm{cm}^{3} ; 07 \mathrm{R}$ : Oriented strand board made from twigs with the density target of $0.7 \mathrm{~g} / \mathrm{cm}^{3}$; P7R: Particle board made from twigs with the density target of $0.7 \mathrm{~g} / \mathrm{cm}^{3}$; OPOTR: Three layers of oriented strand 
board:particle board:oriented strand board (1:1:1) made from twigs with the density target of $0.7 \mathrm{~g} / \mathrm{cm}^{3}$.

\section{Acknowledgements}

The authors would like to thank the Directorate of Research and Community Services, Ministry of Research Technology and Higher Education of the Republic of Indonesia for their financial support under the research scheme of the National Strategy Research (PSN) for the Fiscal Year 2017. The authors would also like to thank PT. Sumber Graha Sejahtera, Balaraja Tangerang Indonesia, for their equipment and assistance.

\section{Authors' contributions}

EMA: managed the implementation, controlled and collected research data for the manuscript preparation. Sutrisno: analyzed and reviewed data of physical characteristics of wood-bonded products. IS: analysis and review of mechanical characteristics of wood-bonded products. AD: analyzed and reviewed the manuscript. YS: analysis of surface properties of wood from community forest. YH: collected and analyzed data of the surian tree. All authors read and approved the final manuscript.

\section{Funding}

This research was done under the financial support of the Directorate of Research and Community Services, Ministry of Research Technology and Higher Education of the Republic of Indonesia (LPPM.PN-7-54-2017) for the scheme of Strategic National Research (PSN) 2017.

\section{Availability of data and materials}

There are data and materials obtained during research followed by analyzed, discussed and concluded appear in the manuscript.

\section{Competing interest}

Not applicable.

Received: 25 October 2019 Accepted: 24 March 2020

Published online: 07 April 2020

\section{References}

1. Budiaman A (2000) Quantification of small round wood harvesting waste in natural forest exploitation (in Indonesia). Jurnal Teknologi Hasil Hutan, Indonesia 8(2):34-43

2. Muhdi M, Hanafiah DS (2007) Impact of low harvest wood impacting damage to living stays in natural forests (Case study in the concession area of PT. Suka Jaya Makmur, West Kalimantan) (in Indonesia). Jurnal IImu-IImu Pertanian Indonesia (JIPI) 9(1):32-39

3. Walker JFC (1993) Wood panels: particleboards and fiberboards. Primary wood processing principle and practices. Chapman \& Hall, London, pp $419-478$
4. Maloney TM (1993) Modern particleboard and dry process fiberboard manufacturing. Miller Freeman Inc., San Francisco

5. Wieland S, Pizzi A, Grigsby W, Warnes J, Pichelin F (2006) Microcrystallinity and colloidal peculiarities of UF/Isocyanate hybrid resin. J Appl Polym Sci 104:2633-2636

6. Wescott JM, Traska AE, Frihart CR, Lorenz L (2005) Durable soy-based adhesive dispersions. http://www.forestprod.org/adhesives05wescott. pdf. Accessed 8 Oct 2009

7. Bowyer JL, Shmulsky R, Haygreen JG (2003) Forest products and wood science an introduction, 4th edn. lowa State Press, lowa

8. Hermawan A, Ohuchi T, Fujimoto N, Murase Y (2009) Manufacture of compositeboard using wood prunings and waste porcelain stone. J Wood Sci 55:74-79

9. Nasser RAS (2012) Physical and mechanical properties of three-layer particleboard manufactured from the tree pruning of seven wood species. World Applied Sci J 19(5):741-753

10. Chung MJ, Wang SY (2019) Physical and mechanical properties of composites made from bamboo and woody wastes in Taiwan. J Wood Sci. https://doi.org/10.1186/s10086-019-1833-1

11. Rahman KS, Shaikh AA, Rahman MdM, Alam DNM, Alam MdR (2013) The potential for using stem and branch of bhadi (Lannea coromandelica) as a lignocellulosic raw material for particleboard. Int Res J Biol Sci 2(4):8-12

12. Maraghi MMR, Tabei A (2018) Effect of board density, resin percentage and pressing temperature on particleboard properties made from mixing poplar wood slab, citrus branches and twigs of beech. Wood Res J 63(4):669-682

13. Alamsyah EM, Sumardi I, Sutrisno Darwis A, Suhaya Y (2018) Bond quality of laminated wood made from surian (Toona sinensis Roem) and sengon (Paraserianthes falcataria L. Nielsen). J Biol Sci 18(1):32-38

14. Japanese Industrial Standard (2003) Japanese Industrial Standard JIS A 5908 for Particleboard. Japanese Standard Association, Japan

15. Massijaya MY, Hadi YS, Tambunan B, Sunarni I (1999) Study of particle board manufacturing from wood waste and polystyrene plastic (in Indonesia). Jurnal Teknologi Hasil Hutan, Indonesia 12(2):29-36

16. Okai R, Frimpong Mensah K, Yeboah D (2004) Characterization of strength properties of branchwood and stemwood of some tropical hardwood species. Wood Sci Technol 38(2):163-171

17. Marra AA (1992) Technology of wood bonding principles in practices. Van Nostrand Reinhold, New York

\section{Publisher's Note}

Springer Nature remains neutral with regard to jurisdictional claims in published maps and institutional affiliations.

\section{Submit your manuscript to a SpringerOpen ${ }^{\odot}$ journal and benefit from:}

- Convenient online submission

- Rigorous peer review

- Open access: articles freely available online

- High visibility within the field

- Retaining the copyright to your article

Submit your next manuscript at $\boldsymbol{\nabla}$ springeropen.com 